\title{
Sovereignty Versus Supranationality: The ECOWAS Conundrum
}

\author{
Dr. Michael P. Okom \\ Senior Lecturer, Faculty of Law, University of Calabar, \\ Calabar, Nigeria, West Africa
}

doi: 10.19044/esj.2016.v12n23p289 URL:http://dx.doi.org/10.19044/esj.2016.v12n23p289

\begin{abstract}
The formation of any regional (supranational), body requires the surrender of a measure of sovereignty for the purpose of making the body sturdy and effective. ECOWAS member States have since its inception, demonstrated a noted reluctance to become fully committed to the tenets of the ECOWAS. They are still hanging on in a prehensile manner to their respective national laws, regulations and practices, leaving ECOWAS without any real grip on the organisation. This has left ECOWAS weak, (almost comatose), and unable to deliver on the great promises it made during its inauguration. These are the issues that this paper incisively analyses.
\end{abstract}

Keywords: Commonality, community; eco-currency; liberalisation; nationalism; NEPAD; prosperity; sovereignty; supranationality

Sovereignty is the power of a State to make laws and maintain effective control of its territory. A supra-natural entity has been described as a "super -State or supra -national authority with commensurate powers, able to enforce conformity" on its members. (Gowon 1984: 2). The Economic Community of West African States was conceived as a supranational entity, a Community made up of 16 Member States, run by a Commission, administered in a Secretariat.

The ECOWAS Treaty, after a chequered history, was signed in Lagos on May $28^{\text {th }} 1975$ by 11 Heads of State and four plenipotentiaries, representing 15 West African countries. (Akinyemi, Falagan:1983:3).

Article 2 of the Treaty States that "It shall be the aim of the community to promote cooperation and development in all fields of economic activity. For the purpose of raising the standard of living of its people's., and fostering closer relations among its members.', 
The Member States pledged to make every effort to plan and direct their policies with a view to creating favourable conditions for the achievement of the aims of the community and enjoined each Member State to, "take all steps to secure the enactment of such legislation as is necessary to give effect to the treaty."(Art.3).

In order to strengthen the Community, under Article 3 of the Revised Treaty, the Community is to, by stages ensure the harmonisation and coordination of national policies and the harmonisation of integration programmes, projects and activities, the promotion of the establishment of joint enterprises; the establishment of an economic union through the adoption of common policies in the economic, financial, social and cultural sectors, and the creation of a Monetary Union. Further, the Member States undertook to create favourable conditions for the attainment of the objectives of the Community and take necessary measures to harmonise their strategies and policies and to refrain from any action that may hinder the attainment of the Community's objectives.

However, Member States are unwilling to make the requisite political concessions for the purpose of making the organisation to function properly.

This raises the logical question as to how and to what extent ECOWAS can play a supranational role. (Sahel and West Africa Club, ed.:71). Indeed, an analogous question is whether ECOWAS really has (the supranational) authority to force States to respect its protocols. This authority can only derive from the component units of the supranational organisation. In the words of Oluyemi Adeniji, ECOWAS:

adopted and spearheaded the principle of functional cooperation as an approach to the development of Africa. The functionalism doctrine, has it that there is need for a supernatural authority to replace the various competing nation -states.. However, in establishing such an authority, states.. should not transfer their formal sovereignty but should only transfer executive authority for specific purposes. Thus, contrary to the United States of

Africa advocated by Ghana's Kwame Nkrumah, which would have required the surrender of formal sovereignty, the functional approach only required delegated, conditional and limited authority. (2005:10).

As a supranational entity, ECOWAS was to gestate a Monetary Union, Customs Union, Economic Union and economic integration, by the creation of a common market, characterised by liberalisation of trade, single currency and common external tariff, et al. The legal foundation for monetary integration was laid down in Articles 51 - 55 of the Revised Treaty. They state, inter-alia, that in order to promote monetary and 
financial integration and thereby facilitate intra-community trade in goods and services, Member States undertook to establish a Community Central Bank and a common currency zone. In order to ensure free movement of capital, a Capital Issues Committee was put in place, with the responsibility to see to the unimpeded flow of capital within the Community by removing controls on the transfer of capital, encouraging the establishment of national and regional stock exchanges and the interlocking of capital markets and stock exchanges and the ECOWAS single currency. (Masson, Pattillo 2001:204).

In furtherance of the goals of monetary integration, the ECOWAS Monetary Cooperation Programme (EMCP) was set up by the Authority of Heads of State and Government of ECOWAS in 1987, to bolster intraregional payment systems, achieve monetary stability and deepen financial systems. (Nnanna 2006:33).

The Community set 1994 to achieve monetary union, failed, extended it to 2000, failed, then 2009 and failed again. The erstwhile Governor of the Central Bank of Nigeria, Professor Chukwuma Soludo had asserted in 2005 that "the .. common currency for the Economic Community of West African States (ECOWAS) would take off by December, 2009."

A climate of rivalry has also developed. The Eco currency, (Osagie 2008:2). in the mind of some stakeholders and drivers of the vision is supposed to have a strong stable currency to rival the CFA.

As things stand, the lofty goals of the founding fathers of ECOWAS are being sacrificed at the shrine of rigid sovereignty.

Obadan and Egbon (NIIA, 1994:54,55). have commented thus:

The will to integrate is very much shaky. And... the lack of political will and commitment to implement community decisions has been a major stumbling block to integration efforts. At the level of the Authority of Heads of State, there is every indication of political commitment during ECOWAS summit meetings. But the political input at the national level tapers off soon after... After many years of attaining political independence, factors such as economic nationalism and attachment to notions of sovereignty are still very strong and exert a negative influence on implementation of community decisions.

The intriguing question and the kernel of the author's thrust is, why did the ECOWAS Member States came together in 1975, reaffirmed that concourse in 1993, and said, "By this Treaty the "HIGH CONTRACTING PARTIES: establish among themselves an Economic Community..", while it is very obvious that all along, they were "jealously guard(ing) their 
sovereignty."(Akinyemi,Falegan:563). Equere has aptly commented that "an integration problem would arise where the expected cooperation is not forthcoming from Member States because of $t$ heir unwillingness to surrender part of their sovereignty, since the coordination of economic planning and economic politics.. demands it.” He accuses ECOWAS Member States of "narrow - minded economic nationalism.".

Dr. Bundu Chambas, the erstwhile Secretary of the ECOWAS has lamented that the protocols adopted to facilitate movement of passengers and goods across borders have not made any difference to the constant harassment that road users are subjected to on West African highways. The author interviewed a woman from whose underwear, one thousand U.S dollars were forcefully removed at the Seme border, (the border between Nigeria and Benin Republic). Despite the fact that there is no regulation forbidding taking money across the borders. She had hidden the dollars in her underwear in order to forestall what she eventually fell victim of. A commuter, recounting his experiences at the borders, said that customs officials at the Ghana/Cote d' ivoire border, extorted twenty thousand francs from him for every cargo. "Before passing the border with goods, you must pay money," he rued.

For the past nine years, efforts towards putting in place a common tariff have been on. The goal is to get the Member States to introduce the regional mechanism for a Customs Union and Common External Tariff into the budgetary and fiscal policy scheme of the Member States. But the harmonisation of the customs code and valuation forms was initiated and abandoned. Draft legislation to create a supranational framework to manage issues of competition and investment for the purpose of enhancing the free movement of goods and capital has been drawn up but it has been filed off.

The ECOWAS Trade Liberalization Scheme, set up in 1989 for the purpose of relaxing customs and tariff barriers in order to enable people and goods move fluidly within the sub-region, has not yet become functional. The Member States do not consider it a matter of urgency to get it going. The Member States still apply their own regulations.

In the mid-twentieth century, interstate relationships were encouraged. As Asiwaju has pointed out, the sub-region had had robust intercourse and that West Africa had always been "a natural common market of considerable antiquity." (In Akinyemi et al(ed.):3). He further points out that" as reflected in the records of early European explorers, trade was the main medium of contact among the West African people..The diaries of Captain Hugh Clapperton and the Lander brothers...indicate the remarkable extensiveness of socio-economic interaction among West Africans... before the era of European political intervention”. (Akinyemi et al(ed.):3). There is no doubt therefore, that there is an essential "continuity form antiquity" 
(Akinyemi et al(ed.):3). of the idea of socio-economic integration in the West Africa sub-region.

So, what is going wrong? Why have the ECOWAS Member States balked at riding the wave of "brotherhood" that was generated by the region's pre-colonial forbears? The reasons are nor far-fetched. First, even though the colonial powers talked much about integration, they were very stern about defining their spheres of influence/control, which they ran like fiefdoms. In order for them to do this effectively, they had to stratify the region into rigid colonial "enclaves". Exploitation was the directive principle of colonialism. The colonial powers manifested greed and an insatiable quest for the material endowments of their domains.

This is one of the main reasons why the political leaders hold so tightly to sovereignty because integration would mean relaxing their grip on their fiefdoms. Coupled with their loatheness to share economic resources which they consider personal, integration is anathema. Though they hardly put it in such plain terms, as the hackneyed axiom goes, "actions speak louder than words." Flowing from the foregoing, the author aver that sovereignty is merely a moniker for the monopoly of political power and wielding clout. If the political leaders had the interest of the region at heart, integration would not have been handled in the wan and non-challant manner that it has been.

In March, 2000, the presidents of some ECOWAS States met at the ECOWAS Secretariat in Abuja, the capital of Nigeria to revive efforts at integration. In his report, Yusuf Zango stated thus:

For the first time in its 25 year history, leaders of... ECOWAS appear to have realized

that the world is not standing still for them to play catch - up. In what seems like a wakeup call, Heads of State from Nigeria, Benin, Niger, Ghana, Togo and Burkina Faso met... to agree on measures aimed at ensuring the integration of their economies.. (Zango 2000:1).

They pledged to eliminate rigid border formalities and procedures through the use of passport scanning machines. They directed that the number of personnel at border posts should be limited to "essential staff. They also agreed to ensure the establishment of a Free Trade Zone.

As at the time of this writing none of those decisions have been implemented. The situation is even worse now than it was then. The chequered scenario is compounded by the fact that the Member States are fragmenting into more micro-groups such as UEMOA (a group of French speaking countries), the Mano River Union and the Chad Basin Development Authority. Thus, the Member States are shrinking further and further into smaller shells where they will find it easier to put on their 
sovereignty teflon, while ECOWAS as a supranational entity becomes weaker and weaker.

In 2003, the ECOWAS began negotiations for an Economic Partnership Agreement (EPA), with the European Union (EU). As stated in the ECOWAS 2007 Report, "through the new and more global approach, the EPA is to ensure the integration of the West African countries into the world economy."

As of 2008, the "negotiations" were still on. As at the time of this writing, they are in abeyance. The reason is not far- fetched. The European Union would prefer to deal with a strong regional body that is able to "talk and walk", in other words, match words with action. The EPA, if it had been actualized, would have facilitated access of ECOWAS products to the European market and the integration process would have enjoyed a big boost. But how is this to be when ECOWAS shows up at the negotiating table in "diapers" whining, and later stops showing up? The EPA would have enabled the development dynamic to be re-launched by creating an enabling environment for business to blossom. ( ECOWAS Report, 2007: 117.) This goal is as yet, unrealised.

The main objectives of the ERA were: The gradual creation of a free trade area between the ECOWAS and the EU, compatible with World trade Organisation (WHO) rules; institution of trade and economic relations between West Africa and the EU, giving priority to development and poverty reduction, which was the prime objective of the Cotonou

Agreement; deepening the regional integration process in West Africa and making it the principal base for the development of commercial trade with the outside world and improving access of West African exports to the market through the standardisation and removal of non-tariff barriers. As salutary as the idea of the ERA is, it will remain a mirage so long as West Africa remains disorganised. All told, ECOWAS has admitted that so far, the parties "have not succeeded in determining consensually all the constituent elements of the development dimension of the ERA as well as the best way of transcribing them into the text of the agreement. (ECOWAS Report, 2007: 124).

As the author has consistently argued in this article, sovereignty is the spanner in the works. In a veiled admittance that sovereignty is still a huge obstacle, the ECOWAS Commission said:-

Although significant achievements have been made on the regional integration front, an enormous amount of work still remains to be done with regards to the domestication of regional programmes and policies into national development strategies and programmes of Member States. The achievement of the 
goals of integration requires the constant support and commitment of the Member States of the Community... Member States are therefore urged to ensure the speedy ratification and effective implementation of all outstanding protocols relating to the regional integration process. (ECOWAS Report, 2007:168).

In plain language, the Commission is saying that the ECOWAS integration scheme is a failure, due to the rigid adherence of Member States to sovereignty. To reverse this, States should show more commitment to the ECOWAS Treaty by loosening their tight hold on their sovereignty and cooperate with the Commission to make integration work.

The commission went further the assert more pungently that: a major problem that the region has to confront is the failure of ECOWAS Member States to translate effectively the regional approach into an appropriate national policy framework. In the Member States, there is little evidence of regional integration being seen as a real national priority. The integration process has not had any significant impact on the development of Member States...because of the low level of implementation of Community Acts and Decisions. ( 2007 Report: 169).

The Commission went on to add that "ideally, given the commitment to a regional approach, government business should be organized and conducted with the primary objective of meeting the obligations of the ECOWAS integration agenda.” (2007 Report: 169).

\section{Conclusion}

Integration is a worldwide trend and developed nations that used to have a lukewarm attitude to regional integration now work actively for the promotion of regional cooperation. This underlines the urgency of the need for developing countries to work together to promote economic development in a world that is becoming increasingly complex.

The prevailing economic realities in Africa make cooperation among African countries very crucial. Africa is now saddled with Goliathlike challenges and like David, needs five "stones" to deal with the challenges: cooperation, commitment, good governance, political interdependence and increased economic productivity. All this would require that African States now more than ever need to play down their differences and put up a more cohesive and unified front. (Ladan 1994:19). Africa is plagued with the problems of internally displaced persons, outmoded and decaying infrastructure, disease pandemics like malaria, yellow fever and polio, corruption, famine, poverty and conflict. A child in Africa dies of disease, famine or conflict every three seconds; 200 million people have no 
access to health services; $46 \%$ of the population survive on less than one us dollar a day; primary school enrolment is less than ten percent. (Kimfe 1999:1).

The New Partnership for African Development, (NEPAD), offers another perspective of the imperatives of regional integration in Africa. NEPAD is the new spirit of African leaders coming together to help themselves and be our brothers keepers. In the words of Ladan, "NEPAD is based on the realization that in the current global environment, we all survive or sink together." (Ladan:20). Within the context of NEPAD, it was generally expected that ECOWAS would play a leading role. This was because, the South African Development Coordination Conference (SADCC), formed to fight apartheid and increase development among Southern African countries; the Common Market for Eastern and Southern Africa, (COMESA), the Inter-Governmental Authority for the Horn of Africa, (IGAD), and the Magreb Union for North Africa and Arab States, were all smaller, faltering and COMESA and the East Africa Customs Union were wrangling over tariffs. ECOWAS, with Africa's Big Brother, Nigeria, in its ranks, had the opportunity, but unfortunately lacked the capability, to "be in the vanguard of NEPAD for African reform." (Ikwele 2003:16). The result is that NEPAD has virtually become just a notepad of grand and high falutin objectives.

In order to play the role of "Big Brother" effectively, Nigeria should put its house in order, by entrenching the virtues of good governance and equal opportunity into its body-politic. It should be in the vanguard of the battle to get States to implement adherence to the ECOWAS' protocols and decisions. Currently, the absence of an exemplary leader is a very big problem. If Nigeria steps into that lacuna, that problem would, over time, be solved and Nigeria's example would become the motivation and persuasion for other Member States to follow suit. When this happens, it will not take ECOWAS too long to escape from the sovereignty and supranationality conundrum and usher the region into an era of prosperity ad global competitiveness, in line with the New International World Order.

\section{References:}

Adeniji Oluyemi, The Footprints of Nigeria's Integration Programmes in Africa's Development, Ministry of Cooperation and Integration in Africa (MCIA), Publication on "The Challenges of Cooperation and Integration in the $21^{\text {st }}$ Century", Edited by the Department of Planning, Research and Statistics, July, 2005.

African Regional Integration: Nigerian Policy Perspectives for the 1990s, Lagos: Nigerian Institute of International Affairs, NIIA, 1994. 
Akinyemi, A. B., Falegan, S. B., Aluko I. A., (ed), Readings and Documents on ECOWAS, Lagos; Nigeria Institute of International Affairs, (NIIA) Publication.

Business Times, Nov. 17 - 23, 2003.

ECOWAS Report, 2007.

ECOWAS Revised Treaty 1983.

ECOWAS Treaty 1975.

Gowon, Y., The Economic Community of West African States: A Study in Political and Economic Integration, (Unpublished Ph.D. Thesis, Faculty of Political Science, University of Warwick, London.

Information available on www.nigerbestforum.com. (Last visited 10 -5-10). The CFA is the Franc, the currency of French - speaking West Africa.

Kimfe, A., The Challenges and Prospects of Pan - African Economic Integration, Occasional Papers, No. 12, June/July 1999.

Ladan, M. T., Introduction to ECOWAS Community Law and Practice: Integration, Migration, Human Rights, Access to Justice and Security, Zaria: Ahmadu Bello University Press, 1994.

Masson Paul and Pattillo Catherine, "Monetary Union in West Africa, (ECOWAS): Is it Desirable And How Can it Be Achieved?"www.inf.org .xternalpubs /Feb .14,2001.

Medium and Long - Term Regional Development Perspectives in West Africa, (Symposium held for the $30^{\text {th }}$ Anniversary of the Economic Community of West African States, ECOWAS, in Abuja, Nigeria, on May 25 and 26, 2005, Summary of Work and Debates), Edited by the Sahel and West Africa Club.

Nnanna, O. J., ECOWAS Common Exteral Tariff, The Comet Newspaper, Jan. 4, 2006.

Osagie, E., The Relevance of Common Currency to Regional Economic Integration' :Issues of Monetary Integration in ECOWAS, www. Nigeriabestforum.com; 2008.

The National Concord Newspaper, April 26, 2000 